удк 330.35

\author{
Байкальский государственный университет, \\ Иркутский государственный аграрный университет илени А.А. Ежевского,

\section{ЦЕНОВЫЕ ДИСПРОПОРЦИИ, ВОЗНИКАЮЩИЕ НА СЕЛЬСКОХОЗЯЙСТВЕННУЮ И ПРОМЫШЛЕННУЮ ПРОДУКЦИЮ}

В.И. Самаруха г. Иркутск, Российская Федерация

М.Ф. Тяпкина г. Иркутск, Российская Федерация

\begin{abstract}
АНнотАция. Анализируются ценовые диспропорции, возникающие между промышленными предприятиями, поставляющими сельхозтоваропроизводителям производственные ресурсы (дизельное топливо, удобрения, сельскохозяйственную технику и т.д.) и сельскохозяйственными организациями, использующие эти ресурсы для производства продукции (зерно, молоко, мясо и т.д.). Цены на ресурсы растут быстрее, чем цены на выпускаемую сельскохозяйственную продукцию, что приводит к изыманию доходов у сельхозтоваропроизводителей, использованию амортизационного фонда и незначительной прибыли на поддержания текущей деятельности, $\kappa$ накоплению задолженности перед бюджетом, внебюджетными фондами и банками. Возникающие ценовые диспропорции снижают доходность у сельхозтоваропроизводителей и возможность для обновления материально-технической базы, что приводит к старению техники и оборудования, снижению производительности труда в сельском хозяйстве, а, следовательно, и к отсутствию условий для ведения расширенного воспроизводства, внедрения передовых технологий и инноваций.

кЛюЧЕВЫЕ СЛОВА. Сельское хозяйство, диспаритет, ценовые диспропорции, воспроизводство.

ИНФОРМАЦИЯ О СТАТЬЕ. Дата поступления 22 апреля 2019 г.; дата принятия к печати 21 июня 2019 г.; дата он-лайн-размещения 15 июля 2019 г.
\end{abstract}

V.I. Samarukha Baikal State University, Irkutsk, Russian Federation

M.F. Tyapkina

A.A. Yezhevsky Irkutsk State Agrarian University,

Irkutsk, Russian Federation

\title{
PRICE DISTORTIONS THAT ARISE IN REGARD OF AGRICULTURAL AND INDUSTRIAL PRODUCTS
}

ABSTRACT. The article analyses the price distortions that arise between industrial enterprises supplying agricultural producers with agricultural products (diesel fuel, fertilizers, agricultural equipment, etc.) and agricultural organizations that use these resources for products manufacture (grain, milk, meat, etc.). The prices for resources are growing faster than the prices for agricultural products manufactured, which leads to withdrawing incomes from the agricultural producers, to using the depreciation fund and to the insignificant profits to maintain the current activities, to accumulating debts to the budget, the extra-budgetary funds and banks. The resulting price distortions reduce the profitability of the agricultural producers and the opportunity to updating the inventory, which leads to aging of the machinery and equipment, to reducing productivity in agriculture, and, consequently, to the lack of conditions for conducting expanded reproduction, for introduction of advanced technologies and innovations.

KEYWORDS. Agriculture, disparity, price distortions, reproduction.

ARTICLE INFO. Received April 22, 2019; accepted June 21, 2019; available online July 15, 2019.

(C) Самаруха В.И., Тяпкина М.Ф., 2019

\section{Baikal Research Journal}


Диспропорции, возникающие в экономических отношениях агропромышленного комплекса, такие как диспаритет цен (соотношение цен на сельскохозяйственную и промышленную продукцию, используемую в сельском хозяйстве) [1-5]; изменения структуры цены, где в розничной цене снижается удельный вес сырья [6]; незагруженность перерабатывающих мощностей, когда предприятия пищевой и перерабатывающей промышленности ограничены в доступности к сырьевой базе [7]; снижение доходности [8-12] и рост цен на сельскохозяйственную технику, оборудование, удобрения, горюче-смазочные материалы, строительные материалы не позволяют осуществлять в должной мере расширенное воспроизводство в сельском хозяйстве. Дискуссия по отставанию роста цен на сельскохозяйственную продукцию получила освещение в научной литературе, начиная с 1992 г. Обоснованием методологии и разработкой практических предложений по паритетности экономических отношений в агропромышленном комплексе занимались ученые-экономисты Н.А. Борхунов [1], В.В. Маслова [1], Д.А. Ползиков [3], В.А. Кундиус [10], Э.А. Сагайдак [4], Д.Б. Эпштейн [5], И.Н. Буздалов [2], И.Г. Ушачев [6].

Паритетность экономических отношений означает равенство участников (паритетов) воспроизводственного процесса независимо от формы собственности и хозяйствования на всех его стадиях на основе формирования единой нормативно-правовой базы регулирования экономических процессов, наличия равных стартовых возможностей для всех товаропроизводителей в условиях государственной политики. Э.А. Сагайдак [4] под паритетом экономических отношений понимается его соотношение с эквивалентным межотраслевым обменом, то есть определенное количество общественного труда, воплощенного в потребительской стоимости продуктов сельского хозяйства, обменивается на равное количество общественного труда, воплощенного в потребительской стоимости продуктов и услуг промышленности, что достигается при сочетании ценовых и финансовых отношениях. Сегодня главной формой эквивалентности межотраслевого обмена в агропромышленном комплексе является паритет цен на продукцию, реализуемую сельхозтоваропроизводителями и цен на приобретаемые ими товары и услуги промышленного происхождения. Критерий паритетности - возможность для сельхозтоваропроизводителей приобрести в отчетном периоде такое же количество промышленных товаров, какое они могли приобрести в базисном периоде.

За годы реформ так и не удалось решить вопрос диспропорции, из-за чего $24,4 \%$ сельскохозяйственных организаций ведут производство себе в убыток. Цены на ресурсы растут быстрее, чем цены на выпускаемую сельскохозяйственную продукцию, что приводит к накоплению задолженности сельхозтоваропроизводителями перед бюджетом, внебюджетными фондами и банками. Динамика роста цен на дизельное топливо и цен производителей сельскохозяйственной продукции показала, что в 2017 г. по сравнению с 1999 г. рост составил на зерно 5,4 раза, молоко - 8 раза, мясо - 5,3 раза (сравнение делаем с 1999 г., так как цены за 1992-1998 гг. указаны в тыс. р. за тонну в статистических сборниках).

Отсутствие государственного регулирование цен поставщиков ресурсов, а также посредников снижает доходность в сельском хозяйстве из-за возникающих диспропорций между ценами на ресурсы и выпускаемую продукцию, так в 1990 г. (см. табл. 1) одна тонна дизельного топлива приобреталась сельхозтоваропроизводителями за 138 р., в 1995 г. - уже за 1247 тыс. р., 2005 г. - 16830 р., в 2010 г. - 24157 р., а в 2017 г. - 46998 р. В плановой экономике действовала система ценообразования, позволяющая регулировать цены на промышленную и сельскохозяйственную продукцию. В 1990 г. тонна дизельного топлива стоила 138 р., тонна зерна - 280 р., то есть для приобретения тонны дизельного топлива

\section{Baikal Research Journal}

электронный научный журнал Байкальского государственного университета 
Таблица 1

Диналика соотношения иены дизельного топлива и реализации объелов продукиии по действующил иенал для его приобретения за 1990-2017 г2."

\begin{tabular}{|c|c|c|c|c|c|c|c|}
\hline \multirow{3}{*}{ Годы } & \multirow{3}{*}{$\begin{array}{c}\text { Средняя цена приобре- } \\
\text { тения } 1 \text { т дизельного } \\
\text { топлива }\end{array}$} & \multicolumn{6}{|c|}{$\begin{array}{c}\text { Требуется продукции для приобретения одной тонны } \\
\text { дизельного топлива }\end{array}$} \\
\hline & & \multicolumn{2}{|c|}{ зерна } & \multicolumn{2}{|c|}{ молока } & \multicolumn{2}{|c|}{ мяса } \\
\hline & & тонн & p. $/ \mathrm{T}$ & тонн & p. $/ \mathrm{T}$ & тонн & p. $/ \mathrm{T}$ \\
\hline 1990 & 138 & 0,49 & 280 & 0,26 & 530 & 0,69 & 200 \\
\hline $1995^{* * *}$ & 1247 & 3,94 & 317 & 1,65 & 757,4 & 0,41 & 3015 \\
\hline 2000 & 7528 & 3,56 & 2113 & 2,07 & 3633 & 0,41 & 18437 \\
\hline 2001 & 7206 & 3,37 & 2138 & 1,62 & 4436 & 0,28 & 25680 \\
\hline 2002 & 7036 & 4,16 & 1690 & 1,63 & 4328 & 0,26 & 27332 \\
\hline 2003 & 9857 & 4,41 & 2233 & 2,02 & 4890 & 0,36 & 27205 \\
\hline 2004 & 12707 & 4,15 & 3060 & 2,18 & 5818 & 0,38 & 33829 \\
\hline 2005 & 16830 & 6,68 & 2519 & 2,52 & 6680 & 0,41 & 41304 \\
\hline 2006 & 16925 & 5,63 & 3008 & 2,35 & 7214 & 0,40 & 42700 \\
\hline 2007 & 19711 & 4,33 & 4549 & 2,34 & 8409 & 0,44 & 44348 \\
\hline 2008 & 20286 & 4,03 & 5036 & 1,84 & 11016 & 0,41 & 48927 \\
\hline 2009 & 19661 & 4,46 & 4412 & 1,89 & 10410 & 0,34 & 57433 \\
\hline 2010 & 24157 & 6,01 & 4017 & 1,95 & 12370 & 0,43 & 56720 \\
\hline 2011 & 30488 & 7,01 & 4348 & 2,16 & 14135 & 0,49 & 62004 \\
\hline 2012 & 34075 & 5,30 & 6424 & 2,50 & 13604 & 0,52 & 65408 \\
\hline 2013 & 36275 & 5,32 & 6824 & 2,29 & 15875 & 0,59 & 61504 \\
\hline 2014 & 36622 & 5,54 & 6616 & 1,87 & 19614 & 0,49 & 75256 \\
\hline 2015 & 40015 & 4,61 & 8684 & 1,94 & 20648 & 0,47 & 85165 \\
\hline 2016 & $\begin{array}{lll}39 & 721\end{array}$ & 4,45 & 8923 & 1,82 & 21814 & 0,48 & 82672 \\
\hline 2017 & 46998 & 6,31 & 7451 & 1,92 & 24487 & 0,57 & 82580 \\
\hline
\end{tabular}

** 1995 г. - цены указаны тыс. р. за 1 т

* Составлено авторами по данным Федеральной службы государственной статистики. URL: http://www.gks.ru/wps/wcm/connect/rosstat_main/rosstat/ru/statistics/publications/catalog/ doc_1135087342078.

надо было продать 0,49 т зерна, то есть в два раза меньше, или 0,26 т молока, что в четыре раза меньше. Чтобы купить в 1995 г. тонну дизельного топлива, необходимо было продать уже - 3,94 т зерна (см. рис. 1), в 2005 г. — 6,68 т, в 2010 г. - 6,01 т, 2017 г. - 6,3 т.

Исходя из регрессионной модели между ценой на дизельное топливо $\left(x_{1}\right)$, и ценой на зерно $\left(y_{x}\right)$ проявилась следующая зависимость - с ростом цены дизельного топлива на 1 р. цена зерна увеличивается на 0,18 р. Связь между исследуемым факторами прямая и тесная, что подтверждается значимостью коэффициентов

\section{Baikal Research Journal}

электронный научный журнал Байкальского государственного университета 


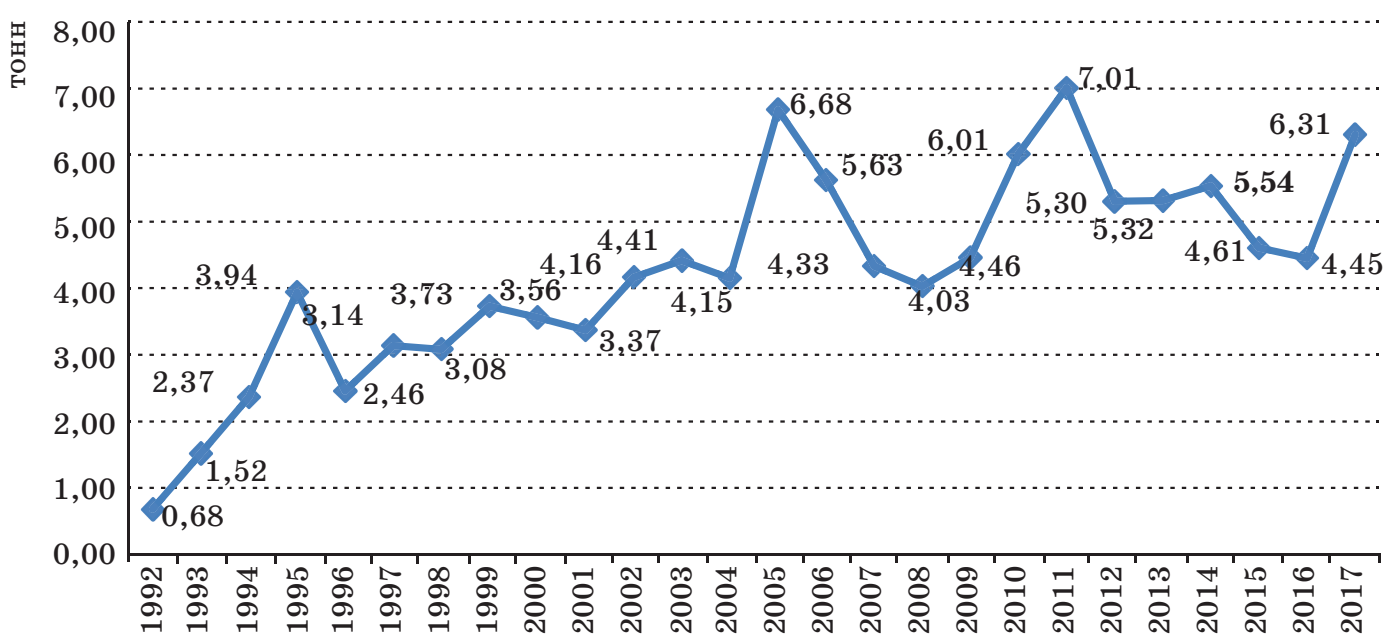

Рис. 1. Требуется тонн зерна для приобретения $1 \mathrm{~m}$ дизельного топлива*

" Составлено авторами по данным Федеральной службы государственной статистики. URL: http://www.gks.ru/wps/wcm/connect/rosstat_main/rosstat/ru/statistics/publications/catalog/ doc_1135087342078.

корреляции (множественный коэффициент корреляции 0,97, коэффициент детерминации 0,94, уравнение регрессии имеет вид: $y=285+0,18 x)$. Стандартная ошибка уравнения регрессии: $\sigma_{v}=185$, оценка качества параметров уравнения регрессии по критерию Фишера показало, что уравнение регрессии значимо, поскольку $F_{\phi}=443$ значительно превышает таблично значение $F T=1,5$. Оценка значимости коэффициентов с помощью $t$-критерия Стьюдента $t_{\text {расч }}=2,01>t_{\text {табл }}=$ $=1,5$ при уровне значимости показывает, что коэффициенты уравнения являются значимы.

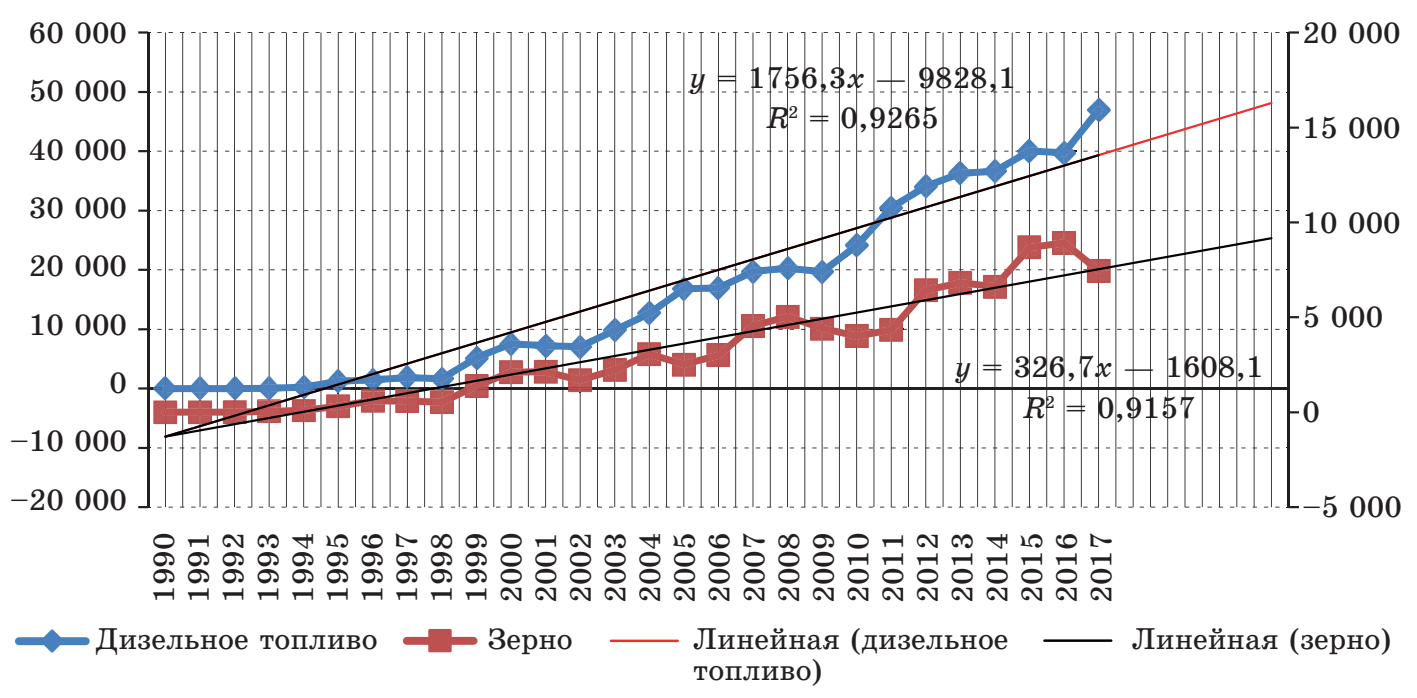

Рисунок 2 - Трендовая лодель иень на дизельное топливо и цень на зерно*

" Составлено авторами по данным Федеральной службы государственной статистики. URL: http://www.gks.ru/wps/wcm/connect/rosstat_main/rosstat/ru/statistics/publications/catalog/ doc_1135087342078.

\section{Baikal Research Journal}


Трендовая модель показала (рис. 2), что увеличение цены дизельного топлива к 2020 г. до 50428 р. за тонну приведет к росту цены на зерно до 9459 р. за тонну, то есть с увеличением цены на дизельное топливо на 1 \% стоимость зерна увеличивается на 0,04 \% (коэффициент эластичности равен 0,04).

Таблица 2

Диналика изленения рыночных иен на производственные ресурсы и сельскохозяйственную продукиию, тыс. р. за $1 \mathrm{~m}^{*}$

\begin{tabular}{|c|c|c|c|}
\hline Показатель & 1991 & 2017 & 2017 г. к 1991 г., раз \\
\hline $\begin{array}{l}\text { Минеральные удобрения: } \\
\text { азотные }\end{array}$ & 0,162 & 39,681 & 245 \\
\hline фосфатные & 0,256 & 59,676 & 233 \\
\hline калийные & 0,107 & 31,385 & 293 \\
\hline $\begin{array}{l}\text { Электроэнергия на производственные } \\
\text { нужды, за тыс. кВт-ч }\end{array}$ & 0,023 & 5,282 & 230 \\
\hline Дизельное топливо & 0,164 & 46,998 & 287 \\
\hline Комбайн зерновой & 34,5 & 8360 & 242 \\
\hline Трактор & 15 & 2412 & 161 \\
\hline Зерновые & 0,2 & 7,303 & 37 \\
\hline Картофель & 1 & 11,607 & 12 \\
\hline Овощи & 1,2 & 47,02 & 39 \\
\hline Скот и птица в ж. в. & 4,7 & 82,58 & 18 \\
\hline Молоко & 0,8 & 24,487 & 31 \\
\hline Яйца куриные, тыс. шт. & 0,2 & 3,565 & 18 \\
\hline
\end{tabular}

" Составлено авторами по данным Федеральной службы государственной статистики. URL: http://www.gks.ru/wps/wcm/connect/rosstat_main/rosstat/ru/statistics/publications/catalog/ doc_1135087342078.

Цены на производственные ресурсы за 1991-2017 гг. выросли на 1,6-2,9 раз, а на продукцию сельского хозяйства на 18-39 \% (табл. 2). Цены на сельскохозяйственную продукцию выросли в десятки раз, а на производственные ресурсы в сотни раз, демонстрируя возникающие диспропорции соотношение цен на сельскохозяйственную и промышленную продукцию, используемую в сельском хозяйстве [6], так в 1991 г., чтобы купить трактор производителю надо было продать 75 т пшеницы, а в 2017 г. уже 330 т., комбайн зерновой производителю обходился в 1991 г. - 173 т пшеницы, а в 2017 г. 1145 т. Чтобы приобрести азотные удобрения в 1991 г. достаточно было продать 0,81 т пшеницы, то в 2017 г. уже 5,4 т, фосфорные - 1,3 т и 8,2 т, калийные $-0,5$ т и 4,3 т, соответственно. Такие диспропорции связаны с тем, что промышленные предприятия самостоятельно определяли и определяют цены на свою продукцию, а цены на сельскохозяйственную продукцию изначально определялись перерабатывающими предприятиями, поэтому цены на промышленную продукцию росли быстрее, чем на сельскохозяйственную. В плановой экономике государство поддерживало сельхозтоваропроизводителей путем регулирования цен на материально-технические ресурсы: технику, удобрения, горюче-смазочные материалы, электроэнергию [13].

\section{Baikal Research Journal}

электронный научный журнал Байкальского государственного университета 
Несмотря на увеличение цен за анализируемый период выручка от реализации продукции не на много превышала затраты на производство, а по отдельным продукциям была ниже, что привело к снижению доходности сельхозтоваропроизводителей и отсутствию средств для обновления материально-технической базы $[14 ; 15]$, что в конечном итоге привело к старению техники и оборудования, снижению производительности труда в сельском хозяйстве.

Отметим, что в дореформенный период сельхозтоваропроизводители получали электроэнергию по цене 1 к. за кВт-ч, в 1991 г. -2 к., в 2017 г. - 5,3 р., что выше в 230 раз. На производство одного центнера молока в среднем расходуется более 50 кВт-ч электроэнергии, одного центнера живой массы на выращивании и откорме крупного рогатого скота - 100 кВт-ч дизельного топлива 16 и 50 кг, соответственно [11]. Цены на дизтопливо росли быстрее, чем цены на молоко в 12 раз и на мясо в 16 раз. Также цены на энергоресурсы росли быстрее, чем на молоко в 8 раз и на мясо в 13 раз.

Таблица 3

Индексы закупочных и розничных иен на основные виды продовольствия за период 1991-2017 г2., в \% к предыдущему периоду"

\begin{tabular}{|c|c|c|c|c|c|c|c|c|}
\hline Показатель & 1991 & 1995 & 2000 & 2005 & 2010 & 2015 & 2016 & 2017 \\
\hline $\begin{array}{l}\text { Зерновые куль- } \\
\text { туры }\end{array}$ & 1,5 & 310,0 & 180,1 & 90,3 & 95,7 & 115,2 & 111,0 & 92,0 \\
\hline $\begin{array}{l}\text { Хлеб и хлебобу- } \\
\text { лочные изделия }\end{array}$ & 44,3 & 320,0 & 116,5 & 103,0 & 107,6 & 113,2 & 105,9 & 102,7 \\
\hline Молоко & 1,4 & 470,0 & 123,9 & 113,9 & 126,8 & 104,1 & 105,8 & 110,6 \\
\hline $\begin{array}{l}\text { Молоко и молоч- } \\
\text { ные продукты }\end{array}$ & 49,4 & 230,0 & 121,1 & 110,5 & 116,7 & 111,5 & 109,5 & 105,2 \\
\hline $\begin{array}{l}\text { Семена подсолнеч- } \\
\text { ника }\end{array}$ & н.д. & 320,0 & 133,5 & 112,1 & 129,4 & 147,2 & 128,4 & 84,1 \\
\hline $\begin{array}{l}\text { Масло подсолнеч- } \\
\text { ное }\end{array}$ & 35,7 & 190,0 & 90,7 & 102,1 & 127,6 & 137,2 & 103,4 & 91,4 \\
\hline $\begin{array}{l}\text { Корнеплоды све- } \\
\text { клы сахарной }\end{array}$ & 1,3 & 260,0 & 145 & 103,8 & 128,3 & 128,3 & 127,1 & 86,8 \\
\hline Сахар-песок & 55,3 & 200,0 & 170,7 & 99,9 & 122,5 & 112,9 & 94,0 & 76,3 \\
\hline $\begin{array}{l}\text { Скот и птица в } \\
\text { ж.в. }\end{array}$ & 1,5 & 320,0 & 124,1 & 122,3 & 99,7 & 113 & 95,9 & 101,4 \\
\hline Мясо и птица & 19,3 & 230,0 & 128,3 & 118,6 & 105,3 & 104,3 & 101,6 & 97,7 \\
\hline
\end{tabular}

" Составлено авторами по данным Федеральной службы государственной статистики. URL: http://www.gks.ru/wps/wcm/connect/rosstat_main/rosstat/ru/statistics/publications/catalog/ doc_1135087342078.

Вызываемые диспропорции между рыночными ценами на производственные ресурсы и сельскохозяйственную продукцию должны были привести к принятию законопроектов по регулированию тарифов на электрическую и тепловую энергию, но анализ показывает, что ситуация для сельхозтоваропроизводителей выглядит с каждым годом удручающе. Изъятие доходов у сельхозтоваропроизводителей через ценовые диспропорции приводит к снижению рентабельности и возможностей для обновления материально-технической базы, а, следовательно, и к отсутствию условий для ведения расширенного воспроизводства.

В 1991 г. в результате либерализации цен произошел резкий рост цен на продукцию сельского хозяйства, при чем, розничные цены росли в десятки раз быстрее (см.

\section{Baikal Research Journal}

электронный научный журнал Байкальского государственного университета 
рис. 3), чем закупочные, что объясняется возросшим спросом населения. Однако, дополнительные доходы получило не сельское хозяйство, а третья сфера агропромышленного комплекса - перерабатывающие предприятия и предприятия торговли. $\mathrm{K}$ 1995 г. рост цен по отношению к предыдущему году снизился, но составлял разы. В результате низких доходов сельскохозяйственные предприятия сокращают производство вплоть до 1998 г., а перерабатывающие предприятия переходят частично на импортное сырье, особенно в сахарной, мясной и молочной отраслях перерабатывающей промышленности, в эти периоды наблюдается больший рост закупочных цен. С 2000 г. закупочные цены на зерновые, молока и масло подсолнечное росли быстрее по сравнению с розничными, что увеличивало удельный вес затрат на сырье конечного продукта, а сельхозтоваропроизводители получали дополнительные доходы.

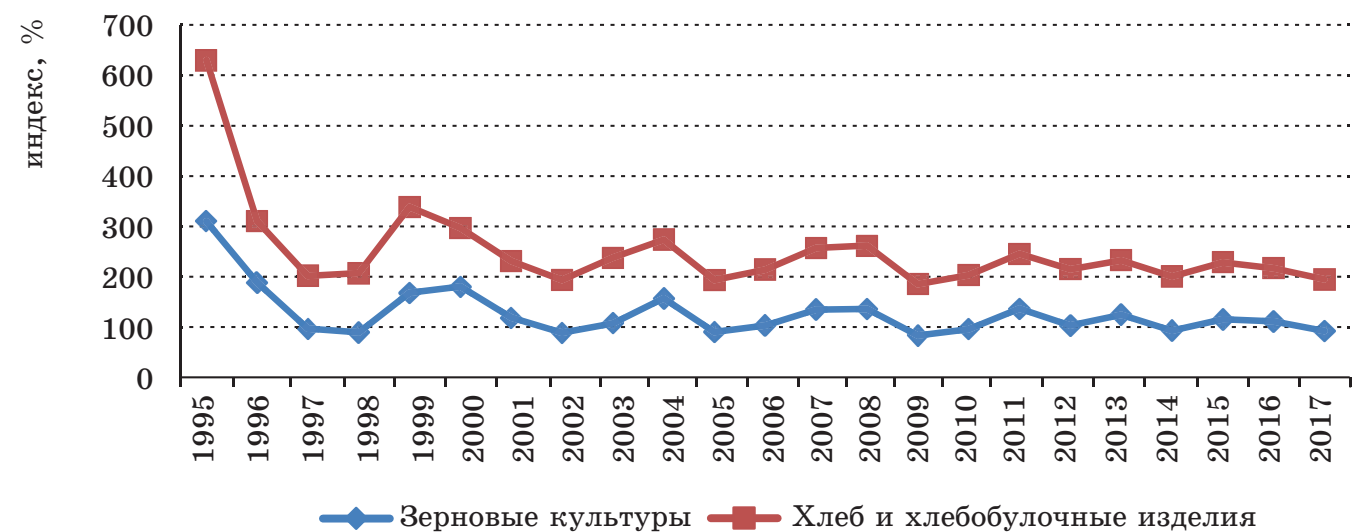

Рис. З. Индекс иен на зерновые культуры и хлеб

и хлебобулочные изделия за 1995-2017 г2."

" Составлено авторами по данным Федеральной службы государственной статистики. URL: http://www.gks.ru/wps/wcm/connect/rosstat_main/rosstat/ru/statistics/publications/catalog/ doc_1135087342078.

Таким образом, вызываемые диспропорции между закупочными ценами на сельскохозяйственное сырье и розничными ценами на основные виды продовольствия снижают и так невысокую доходность сельхозтоваропроизводителей, что приводит к снижению рентабельности и возможностей для обновления материально-технической базы. Необходимы условия для ведения расширенного воспроизводства, что возможно в условия рыночных отношений через механизм государственной поддержки сельхозтоваропроизводителей, использующих сельскохозяйственную технику, оборудование, удобрения, горюче-смазочные материалы, строительные материалы.

\section{Список использованной литературы}

1. Борхунов Н.А. О ценах на зерно / Н.А. Борхунов, В.В. Маслова // Экономика сельского хозяйства России. - 2007. - № 10. - С. 24.

2. Буздалов И.Н. Сельское хозяйство под прессом межотраслевых и макроэкономических деформаций / И.Н. Буздалов // Экономическая наука современной России. 2009. - № 3 (46). - С. 28-42.

3. Ползиков Д.А. Ценовые пропорции развития сельского хозяйства России в контексте отраслевой и макроэкономической политики : дис. ... канд. экон. наук : 08.00.01 : 08.00 .05 / Д.А. Ползиков. - М., 2014. - 170 с.

4. Сагайдак Э.А. Методологические основы паритетности экономических отношений в АПК / Э.А. Сагайдак // АПК: Экономика, управление. - 2010. - № 1. - С. 64-66.

\section{Baikal Research Journal}


5. Эпштейн Д. Паритет экономических отношений сельского хозяйства с другими отраслями и оценка финансовых потерь от его отсутствия / Д. Эпштейн // Международный сельскохозяйственный журнал. - 2002. - № 2. - С. 8-24.

6. Экономические проблемы воспроизводства в АПК России / под ред. И.Г. Ушачева [и др.]. - М. : Энциклопедия российских деревень, 2003. - 455 с.

7. Тертышник М.И. Оценка резервов и диспропорций производственных мощностей предприятий / М.И. Тертышник // Инновационные кластеры в цифровой экономике : труды VIII науч.-практ. конф. с международным участием / под ред. А.В. Бабкина. - СПб., 2017. - C. 410-415.

8. Винокуров Г.М. Рентабельность производства сельскохозяйственной продукции коллективных хозяйств Иркутской области / Г.М. Винокуров, М.В. Винокурова // Экономика и управление: проблемы, решения. - 2018. - Т. 1, № 6. - С. 59-65.

9. Винокуров Г.М. Состояние и перспективы развития растениеводства в агропромышленном комплексе Иркутской области / Г.М. Винокуров, М.В. Винокурова // Экономика и управление: проблемы, решения. - 2017. - Т. 1, № 5. - С. 62-72.

10. Кундиус В.А. Механизм выравнивания паритетности доходов сельскохозяйственных организаций как участников агропродуктового рынка / В.А. Кундиус, М.А. Кальней // Вестник Алтайского государственного аграрного университета. — 2008. — № 11 (49). — С. 91-94.

11. Маркова Г.В. Совершенствование условий воспроизводства в сельском хозяйстве : дис. ... д-ра экон. наук : 08.00.05 / Г.В. Маркова. - М., 2014. - 330 с.

12. Тяпкина М.Ф. Ценообразование как необходимое условие расширенного воспроизводства в сельском хозяйстве / М.Ф. Тяпкина, В.В. Врублевская. - Иркутск : Изд-во ИрГСХА, 2015. - 130 с.

13. Багайников М.Л. Проблемы повышения энергообеспеченности аграрного комплекса Байкальского региона [Электронный ресурс] / М.Л. Багайников // Известия Иркутской государственной экономической академии (Байкальский государственный университет экономики и права). - 2014. - № 1. - Режим доступа: http://brj-bguep.ru/reader/article.aspx?id=18735.

14. Самаруха В.И. Проблемы развития сельскохозяйственного производства в регионе / В.И. Самаруха // Известия Иркутской государственной экономической академии. 2008. - № 5 (61). - С. 16-19.

15. Щукина Т.В. Влияние государственной поддержки на развитие сельского хозяйства страны и региона / Т.В. Щукина, Е.И. Щеколкова // Бизнес. Образование. Право. 2017. — № 3 (40). - C. 89-94.

\section{References}

1. Borkhunov N.A., Maslova V.V. On prices for grain. Ekonomika sel'skogo khozyaistva Rossii = Economy of Russia's Agriculture, 2007, no. 10, pp. 24. (In Russian).

2. Buzdalov I.N. Agriculture under pressure of inter-sectorial and macro-economic deformations. Ekonomicheskaya nauka sovremennoi Rossii = Economic Science of Modern Russia, 2009, no. 3 (46), pp. 28-42. (In Russian).

3. Polzikov D.A. Tsenovye proportsii razvitiya sel'skogo khozyaistva Rossii v kontekste otraslevoi i makroekonomicheskoi politiki. Kand. Diss. [Pricing proportions of developing Russia's agriculture in the context of sectorial and macro-economical policy. Cand. Diss.]. Moscow, 2014. $170 \mathrm{p}$.

4. Sagaidak E.A. Methodological framework of equal share in economic relations in agro-industrial complex. APK: Ekonomika, upravlenie = Agro-Industrial Complex: Economics, Management, 2010, no. 1, pp. 64-66. (In Russian).

5. Epshtein D. Parity of economic relations of agriculture with other branches and assessment of financial losses from their absence. Mezhdunarodnyi sel'skokhozyaistvennyi zhurnal= International Agricultural Journal, 2002, no. 2, pp. 8-24. (In Russian).

6. Ushacheva I.G., Borkhunova N.A., Sagaidak E.A., Maslova V.V. (eds). Ekonomicheskie problemy vosproizvodstva $v$ APK Rossii [Economic Problems of Reproduction in Russia's Agribusiness]. Moscow, Entsiklopediya rossiiskikh dereven' Publ., 2003. 455 p.

7. Tertyshnik M.I. Evaluation of Reserves and Imbalances in Production Capacity of Enterprises. In Babkin A.V. (ed.). Innovatsionnye klastery $v$ tsifrovoi ekonomike. Trudy VIII nauchno-prakticheskoi konferentsii s mezhdunarodnym uchastiem [Innovation Clusters in the Digital Economy. Proceedings of the VIII Scientific and Practical Conference]. Saint Petersburg, 2017, pp. 410-415. (In Russian).

\section{Baikal Research Journal}


8. Vinokurov G.M., Vinokurova M.V. The Profitability of Agricultural Production on Collective Farms of the Irkutsk Region. Ekonomika i upravlenie: problemy, resheniya = Economics and Management: Problems and Solutions, 2018, vol. 1, no. 6, pp. 59-65. (In Russian).

9. Vinokurov G.M., Vinokurova M.V. Condition and Prospects for Development Irkutsk Region Agricultural. Ekonomika i upravlenie: problemy, resheniya $=$ Economics and Management: Problems and Solutions, 2017, vol. 1, no. 5, pp. 62-72. (In Russian).

10. Kundius V.A., Kalney M.A. Mechanism of Leveling Income Parity of Agricultural Enterprises as Participants of the Agri-Food Market. Vestnik Altaiskogo gosudarstvennogo agrarnogo universiteta = Bulletin of Altai State Agricultural University, 2008, no. 11 (49), pp. 91-94. (In Russian).

11. Markova G.V. Sovershenstvovanie uslovii vosproizvodstva v sel'skom khozyaistve. Dokt. Diss. [Mastering conditions for reproduction in agriculture. Doct. Diss.]. Moscow, 2014. 330 p.

12. Tyapkina M.F., Vrublevskaya V.V. Tsenoobrazovanie kak neobkhodimoe usloviya rasshirennogo vosproizvodstva $v$ sel'skom khozyaistve [Pricing as a necessary condition of expanded reproduction in agriculture]. Irkutsk State Academy of Agriculture Publ., 2015. 130 p.

13. Bagaynikov M. L. Problems of Increasing Energy Supply of Agricultural Complex in Baikal Region. Izvestiya Irkutskoy gosudarstvennoy ekonomicheskoy akademii (Baykalskiy gosudarstvennyy universitet ekonomiki i prava) = Izvestiya of Irkutsk State Economics Academy (Baikal State University of Economics and Law), 2014. no. 1. Available at: http://brj-bguep. $\mathrm{ru} /$ reader/article.aspx?id=18735. (In Russian).

14. Samarukha V.I. Problems of Development the Agricultural Production in Region. Izvestiya Irkutskoi gosudarstvennoi ekonomicheskoi akademii = Izvestiya of Irkutsk State Economics Academy, 2008, no. 5 (61), pp. 16-19. (In Russian).

15. Shchukina T.V., Shchekolkova E.I. Influence of the State Support on Development of Agriculture of the Country and the Region. Biznes. Obrazovanie. Pravo = Business. Education. $L a w, 2017$, no. 3 (40), pp. 89-94. (In Russian).

\section{Информация об авторах}

Саларуха Виктор Иванович - доктор экономических наук, профессор, кафедра мировой экономики и экономической безопасности, Байкальский государственный университет, Российская Федерация, г. Иркутск, e-mail: oksalsam@mail.ru.

Тяпкина Мария Федоровна - кандидат экономических наук, доцент, кафедра финансов, бухгалтерского учета и анализа, Иркутский государственный аграрный университет имени А.А. Ежевского, Российская Федерация, Иркутский район, п. Молодежный, e-mail: mft74@mail.ru.

\section{Authors}

Viktor I. Samarukha - Doctor habil. in Economics, Professor, Department of World Economy and Economic Security, Baikal State University, Irkutsk, Russian Federation, e-mail: oksalsam@mail.ru.

Maria F. Tyapkina - Ph.D. in Economics, Associate Professor, Chair of Finance, Accounting and Analysis, A.A. Ezhevsky Irkutsk State Agrarian University, Irkutsk district, Molodezhny, Russian Federation, e-mail: mft74@mail.ru.

\section{Для цитирования}

Самаруха В.И. Ценовые диспропорции, возникающие на сельскохозяйственную и промышленную продукцию / В.И. Самаруха, М.Ф. Тяпкина // Baikal Research Journal. 2019. — T. 10, № 2. - DOI : 10.17150/2411-6262.2019.10(2).10.

\section{For Citation}

Samarukha V.I., Tyapkina M.F. Price Distortions That Arise in Regard of Agricultural and Industrial Products. Baikal Research Journal, 2019, vol. 10, no. 2. DOI: 10.17150/24116262.2019.10(2).10. (In Russian).

\section{Baikal Research Journal}

